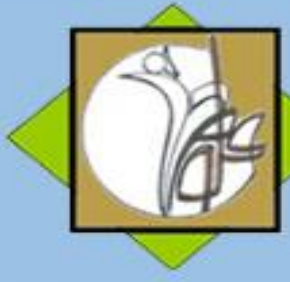

Research Article

\title{
The Relationship between Movement Motivation and Motor Development in Infants with and without Experience of Kindergarten
}

\author{
Shahram Nazarpouri ${ }^{1}$, Abbas Bahram² \\ 1. Shahram Nazarpouri, (Ph. D) Lorestan University, Khorramabad, Iran. \\ 2. Abbas Bahram, (Ph. D) Kharazmi University, Tehran, Iran.
}

\section{ARTICLE INFO}

Received May 2017

Accepted August 2017

\section{KEYWORDS:}

Movement Motivation, Motor Development, Infants, Kindergarten

\section{CITE:}

Nazarpouri, Bahram, The relationship between movement motivation and motor development in infants with and without experience of kindergarten, Research in Sport Management \& Motor Behavior, 2020: 10(20): 31-44

\section{ABSTRACT}

The purpose of this study was to determine the relationship between movement motivation and motor development in infants with and without the experience of kindergarten. The population of this study included all parents with infant's boys with 10 to 11 month in Tehran. Among them, 150 infants with and 150 infants without the experience of kindergarten using the multi-stage random sampling the method was selected as the sample groups. Data collection tools included an infant movement motivation questionnaire and Peabody Developmental Motor Scale-Second Edition (PDMS-2), the data analysis was done using Pearson's correlation coefficient, linear regression, and t-test in a significance level of $p \leq 0.05$. The results showed that there was a significant relationship ( $P=0 / 000)$, between movement motivation and motor development in infants with and without the experience of kindergarten. In the same context, a significant difference $(\mathrm{P}=0 / 000)$, was obtained in movement motivation and motor development between of infants with and without kindergarten experience and infants without the kindergarten experience, movement motivation, and motor development was higher. These results indicate that care of infants in kindergarten Centers may be due to the weakness of the programs and facilities have negative effects on of them movement motivation and motor development. 


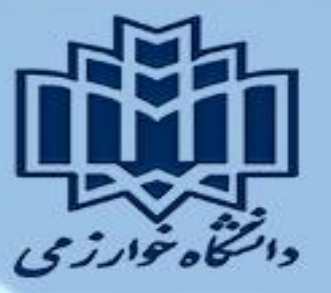

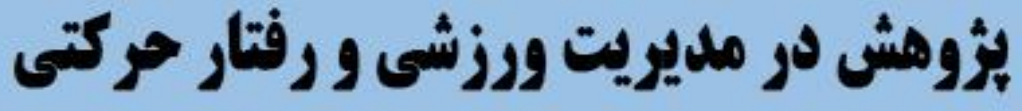

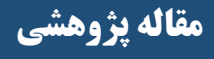

\section{ارتباط بين انكيزش حركتى و رشد حركتى در اطفال دارا و بدون تجربهُ مهدكودى}

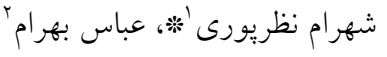 \\ ا. دكترى رفتار حركتى، كروه تربيت بدنى دانشكاه لرستان، خرم آباد- لرستان، ايران.

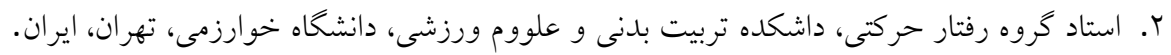

\begin{tabular}{|c|c|}
\hline 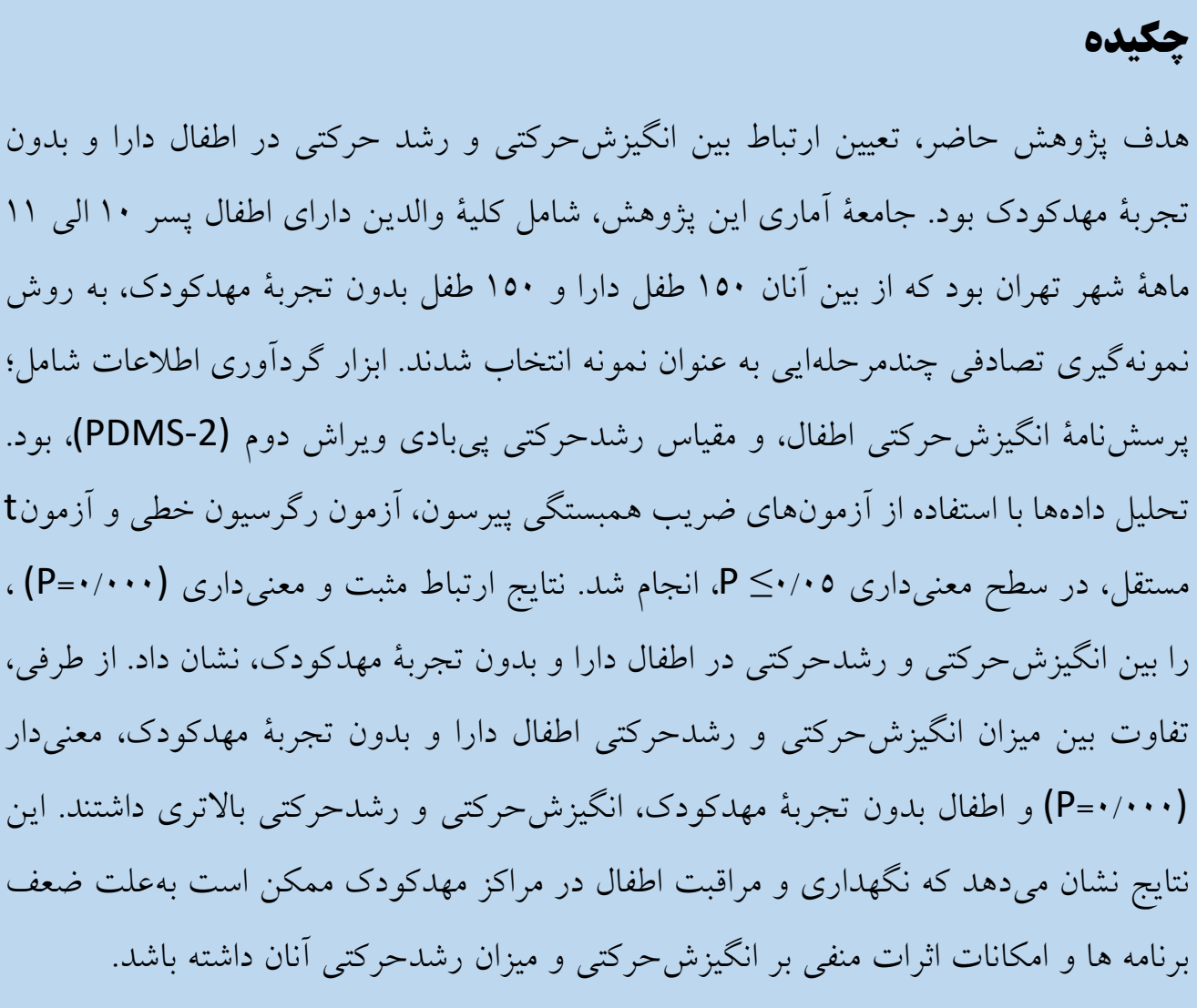 & 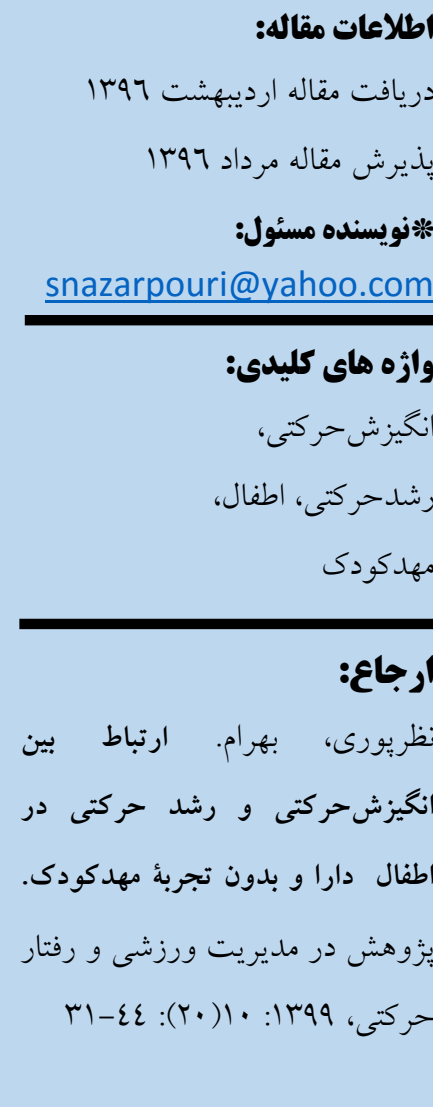 \\
\hline
\end{tabular}




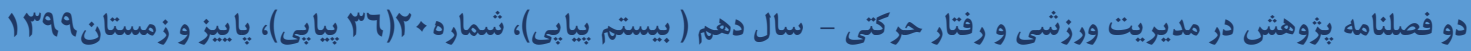

مقلvمه

اطفال؛ همانند لوح سفيدى از قبل آمادهُ شكل يذيرى و الكو گيرى بر اساس ميل ما از يك الكوى از بيش تعيين شده نيستند. محققين براين باورند كه اطفال مىتوانند فكر كنند و بهمنظور كسب اطلاعات محيطى به شيوهاى هدفمند (هرجند در ابتدا بهصورت غيردقيق)، از حركت استفاده كنند (1). رشد انواع الخوهاى حركتى بايه، طى دوران طفوليت از توالى

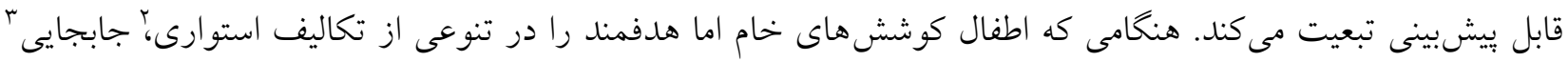
و دستكاى انجام مىدهند، مىبايستى مورد حمايت و تشويق قرار كيرد. محيطى كه محركهاى مناسب را از طريق فرصتهاى فراوان براى تمرين فراهم كند، مى تواند باعث تسريع رشد اين تكاليف شود. در واقع، با توجه به زمان ظهور

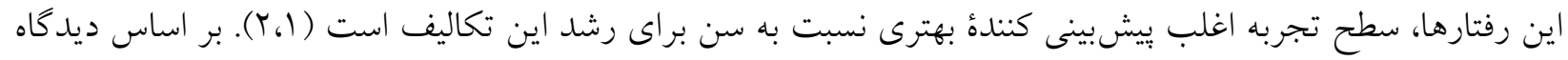
سيستمهاى يويا، الكوى حركتى در نتيجهى تركيب تقريباً نامحدود تعاملات فردى، محيطى و نيازهاى تكليف بهوجود مى آيد. طبق اين ديدكاه سيستمى، رشد حركتى زمانى بهوجود مى آيد كه يك يا جند زيرسيستم تغيير يابد. در حقيقت رشد يك يا جند زير سيستم جديد، حتى مىتواند موجب از بين رفتن زيرسيستمهاى قبلى شود. عامل اصلى تغيير سيستم در اين حالت به عنوان يارامتر كنترلى شناخته مىشود (1). در واقع، بارامترهاى كنترلى به عنوان متغيرهايى كه شرايط و زمينهُ

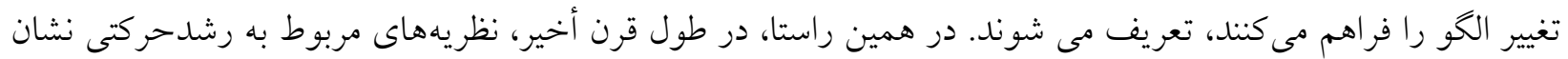
دادهاند كه انكيزه براى حركت ممىتواند به عنوان يكى از ويزگگىهاى درونفردى اطفال، زمينهساز بديدارشدن الكوهاى جديدى از رفتار شود (ץ). محققين انكيزش را بهعنوان سائق و اميالى كه جهت رفتار را بهسمت هدف تعيين مى كنند، تعريف كردهاند. درواقع، آنجه كه به فرد نيرو مىدهد و به رفتارهاى وى انرزى تزريق و آنها را هدايت مى كند، انخيزش

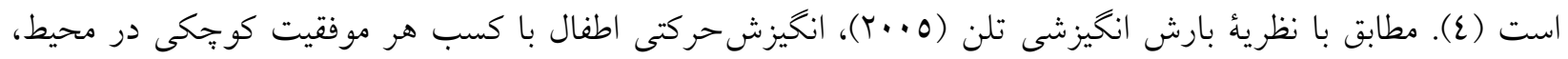

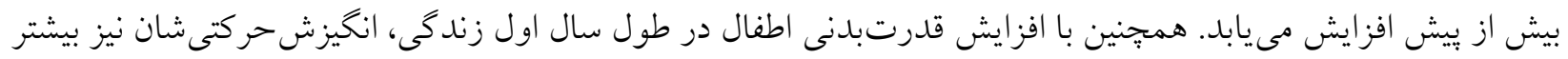
مىشود (0). اطفال نه تنها از لحاظ رشد جسمانى، عاطفى - اجتماعى و همجنين توانايى انجام حركات و فعاليتبدنى، بلكه از لحاظ انخيزش براى حركت يا ميل و ارادهُ فعاليت براى كسب موفقيت، نيز متفاوت هستند (r). با وجود محورى بودن انخيزش براى حركت در نظريههاى رشدحركتى، اين مفهوم در ادبيات بزوهشى بيشتر به عنوان يك متغير سطحى و نه

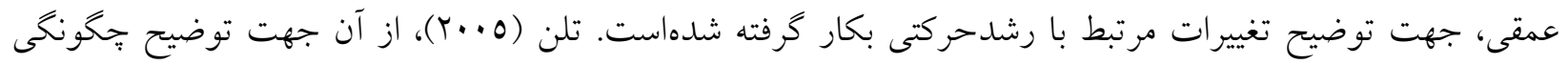

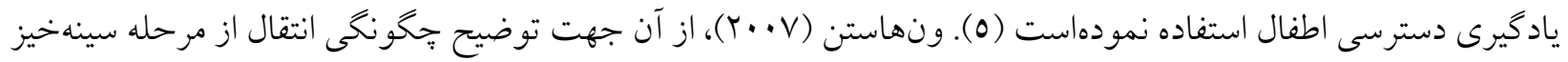
رفتن به راهرفتن استفاده و عنوان نمود كه انخيزش، حركت را هدايت مى كند و حركت پِيه و اساس رشد شناختى است

1. Infants

2. Stability

3. Locomotion

4. Manipulation

${ }^{5}$. Motivation to Move

https://jrsm.khu.ac.ir/ 


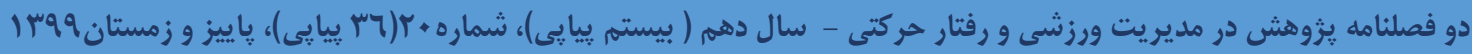

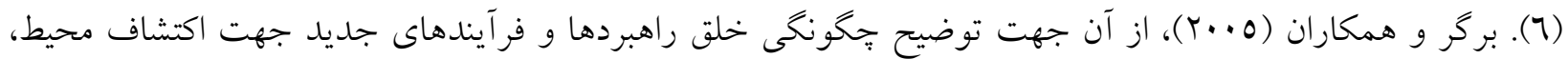
ابزار و اسباب بازىها استفاده نمودهاست (V). در همين راستا، آدلف و وريجكن (1999)، اظهار نمودهاند كه يكى از دلايل تأخير و عقبافتادكى برخى از كودكان نسبت به كودكان ديخر در رشدحركتى مهارتهايى جون سينهخيزرفتن، جهاردستويا رفتن و راهرفتن مستقل، عدم داشتن ميل و رغبت و ميزان انخيزش حركتى مطلوب است (^). همجنين،

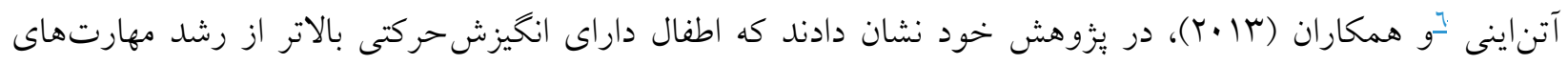

حركتى سريع ترى برخوردارند (r)

انخيزه و رشد حركتى اطفال مى تواند از عوامل محيطى مانند مراكز آموزشى و برورشى نشأت بخيرد (ع). در كشور ما هر

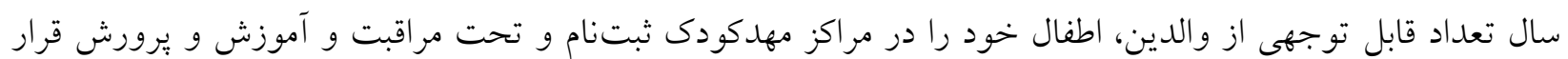
مىدهند. اين مراكز از آموزشها و فعاليتهايى كه از مطالعهُ كودكان و نيازهاى آنها بهره مى كيرند، استفاده مىكنند. برنامهاى مناسب تربيتى در اين محيطها، فضايى براى افزايش انخيزش، ابتكار، خلاقيت و ساز گارى بهوجود مى آورند (1). همجنين، اين مراكز در قالب محيطهاى فراهمساز، فعاليتهايى را در راستاى رشد همهجانبهُ كودكان در زمينههاى شناختى، جسمانى، حركتى و اجتماعى طراحى مى كنند. كنترل شاخص تودهُ بدنى كودكان و ترتيبدادن فعاليتهايى براى رشد و هماهنخى عضلات درشت و ظريف از جملهُ اين فعاليتها مى باشند. تمركز آموزشهاى جسمانى بر بيشرفت و توسعهُ مهارت هاى بالقوه، مفاهيم و متغيرهاى حركتى است. همجنين در اين مراكز، فعاليتهايى جهت افزايش قوه تفكر،

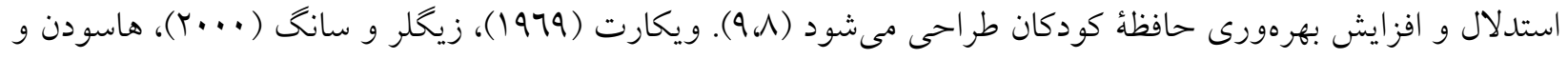

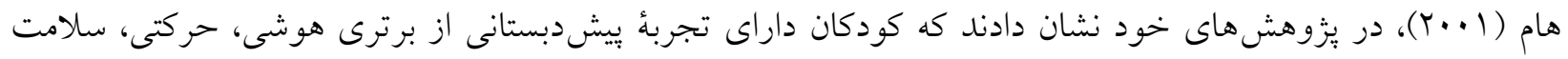

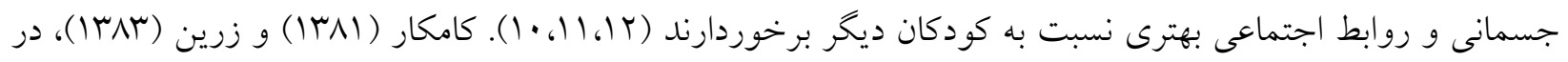
يزوهش هاى جداكانهايى نشان دادند كه فعاليتهاى طرحريزىشده در مراكز ييشدبستانى مثل مهدكودكها در رشد تفكر خلاقانه، قدرت حل مسئله و همجنين رشد توانايى هاى جسمانى، حركتى و كلامى مؤثر هستند ( (1). ليموس و همكاران

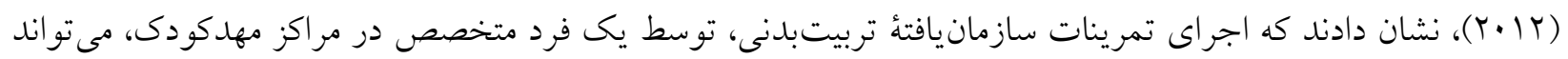

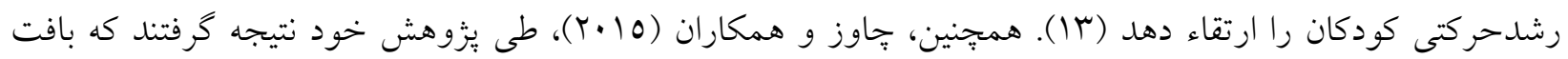

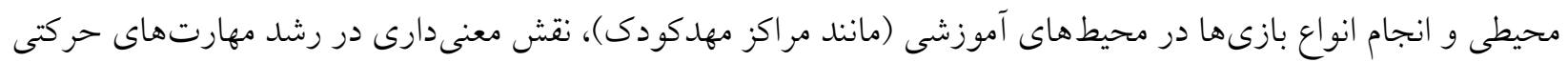
درشت كودكان ايفا مى كنند (ع (1). از آنجه كه در ارتباط با رشد همه جانبه كودكان در زمينهُ انخيزش حركتى و رشد حركتى بيان شد، مى توان نتيجه كرفت كه، اين دو عامل مهم از محيط، تجارب و آموزشهاى حاصل از آن متأثر مىشوند. همجنين با توجه به مبانى نظرى و نتايج تحقيقات ذكر شده مىتوان كفت كه، بين ميزان انخيزش حركتى و رشد حركتى كودكان رابطهُ نزديكى وجود دارد. از طرف ديخر همانطور كه بيان شد، مراكز بيش دبستانى مثل مهدكودكها از جمله محيطهاى فراهم سازى هستند كه، فعاليتهاى را در راستاى رشد همه جانبة كودكان در زمينه هاى جسمانى، شناختى، عاطفى، اجتماعى 


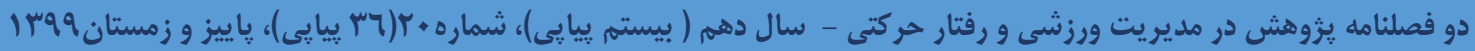

و حركتى طراحى مى كنند. بنابراين، مىتوان اين فرضيه را مطرح كرد كه، كودكان بهرهمند از آموزش و تجارب مراكز مهدكودك، نسبت به كودكان ديخرى كه از اين آموزشى ها محروم هستند، از ميزان انخيزش حركتى و متعاقباً از رشد حركتى بالاترى برخوردارند. لذا، از آنجائى كه تاكنون مفهوم انحيزش حركتى در ادبيات يزوهشى مربوط به رشدحركتى اطفال، كمتر مورد بررسى قراركرفتهاست. محقق برآن شد، يُزوهش حاضر را انجام دهد تا هم ارتباط بين ميزان انخيزش حركتى و رشدحركتى اطفال تعيين شود و هم اثر داشتن يا نداشتن تجربؤ مهدكودى اطفال بر اين متغيرها، مورد بررسى قرار كيرد. بنابراين، يزوهش حاضر با هدف تعيين ارتباط بين انخيزش حركتى و رشدحركتى در اطفال دارا و بدون تجربهُ مهدكودى انجام شدهاست.

\section{روش}

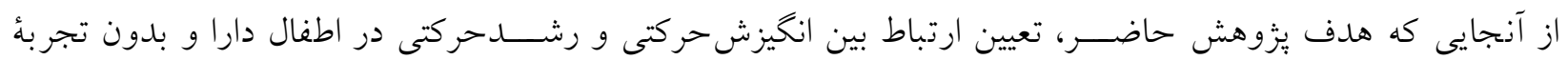
مهدكودى است، براى برر سى ارتباط بين انخيزش حركتى و ر شدحركتى از راهبرد همبستخى و براى برر سى تفاوت اين متغيرها در بين اطفال دارا و بدون تجربهُ مهدكودى از راهبرد على يس از وقوع استفاده شده است. همجنين، روش اين

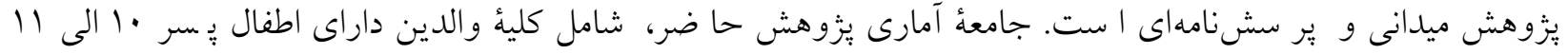

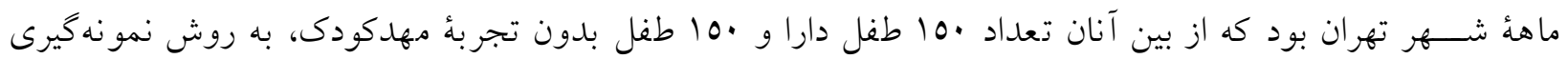
تصادفى جند مرحله|يى، بهعنوان نمونهُ يزوهش انتخاب شدند.

ابزار كردهآورى اطلاعات

در اين يزوهش ابزارهاى مورد اسـتفاده عبارت بودند از: الف) يرسـش نامهٔ محقق سـاختهُ اطلاعات فردى اطفال؛ بعد از مشخصشدن مراكز بهداشت و مهدكودكها، اين برسشنامه بين والدين اطفال توزيع كرديد. بعد از تكميل و جمع آورى برى برى

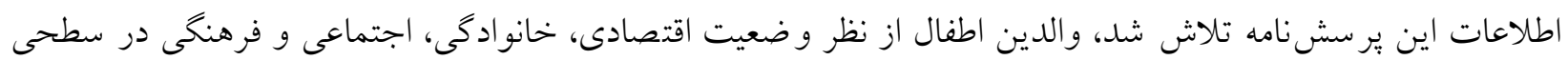
همسان، انتخاب شوند. در انتهاى اين ير سشنامه، رضايتنامهُ موردنياز براى شركت در يزٔوهش جهت ارائه به والدين،

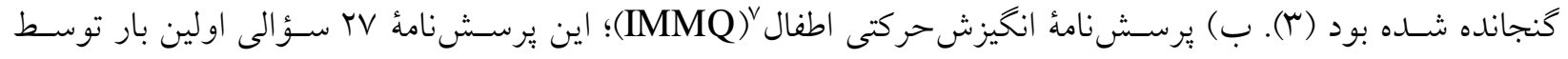

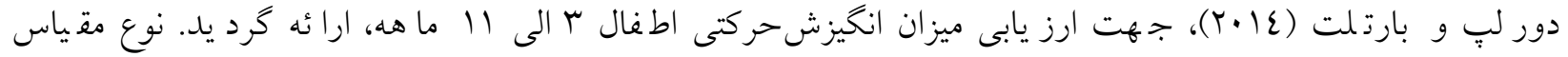
اندازه كيرى اين يرسشنامه از نوع ليكرت ينج ارزشى است كه از گزينههاى "تا حد زيادى" تا "هركز" "يراكندكى دارد و والدين در هر سؤال مىبايست ميزان انكيزشحركتى طفل خود را درجهبندى كنند. زمان لازم براى تكميل اين يرسشنامه

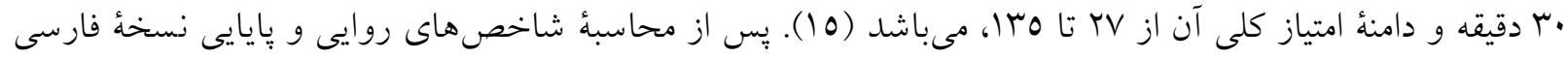

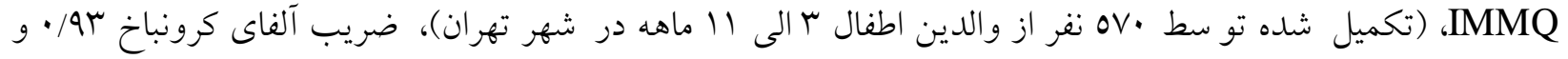

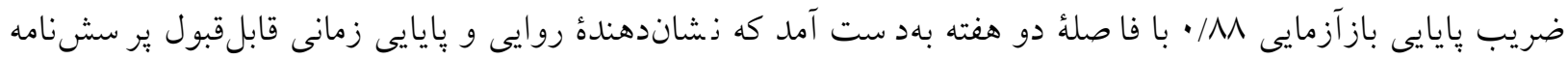

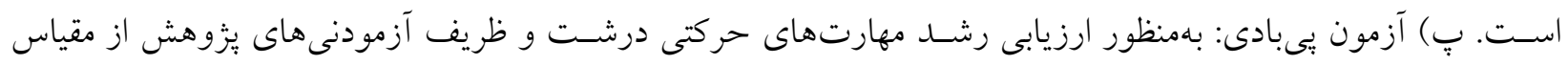

\section{Infant Movement Motivation Questioner}

https://jrsm.khu.ac.ir/ 


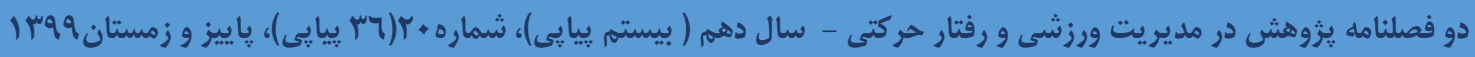

رشدحركتى بى بادى ^استفاده شد. اين مقياس، آزمون هنجاريابى شدهايى است كه مهارتهاى حركتى درشت و ظريف

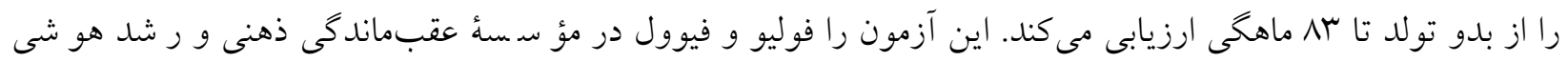
داذ شكده جورج يى بادى داذ شگاه وندربيلت منت شر كردند. آزمون مت شكل از دو خرده مقياس حركتى در شت و ظريف I ست. مقياس حركات در شت شامل •IV ماده l ست كه به IV سطح سنى و ·ا آيتم در هر سطح تق سيم مى شود و مهارتهايى مانند بازتابها، تعادل، ثبات، جابجايى، گرفتن و يرتابكردن اشياء را شامل مى شود. مقياس حركتى ظريف شامل ر Iال ماده است كه به 17 سطح سنى و به 1 ماده در هر سطح تق سيم مى شود و مهارتهاى مربوط به كرفتن،

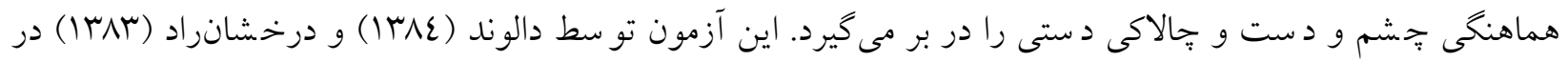

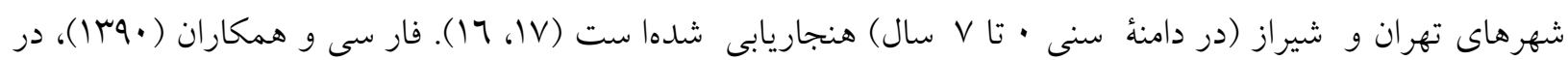

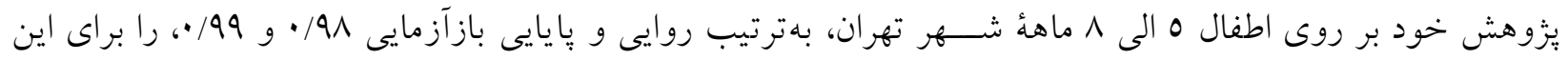

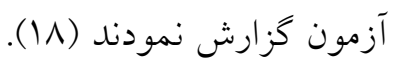

\section{شيوه اجراى تحقيق}

براى اجراى اين تحقيق، ابتدا هماهنكى اوليه با مديران مراكز بهداشت و ادارهُ بهزيستى شهر تهران انجام و با تأييد طرح

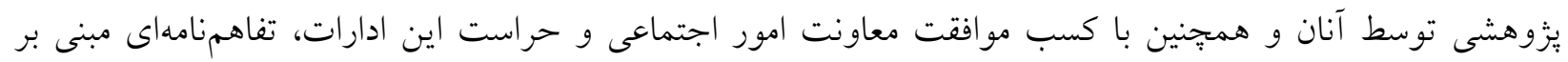
همكارى و رعايت اصول اخلاقى و ايمنى در تحقيق منعقد و محقق به مراكز بهداشت و مهدكودى مورد نظر معرفى شدند.

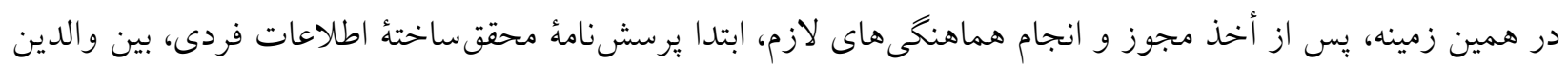

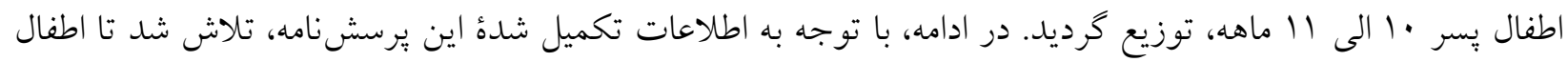

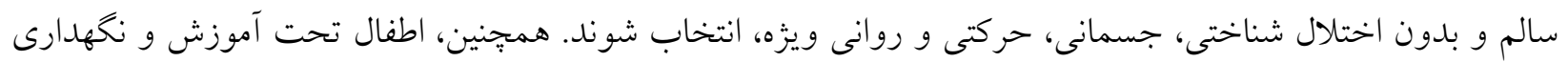
در مراكز مهلدكودى، حداقل تجربهُ ب ماه حضور در اين مراكز را داشتند. در همين راستا، جهت ارزيابى انخيزش حركتى اطفال بدون تجربهُ مهدكودك، يرسشنامهُ انخيزش حركتى بين والدين آنان توزيع و تكميل گرديد. اما جهت ارزيابى بهتر انخيزش حركتى اطفال داراى تجربهُ مهلدكودى، برسشنامهُ مذكور هم توسط مربيان مهدكودى (در زمان حضور اطفال در

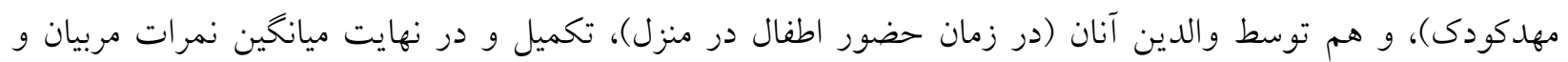
و الدين، ملاكى ارزيابى انخيزش حركتى آنان قراركرفت. در ادامه و يس از تكميل برسشنامهُ انخيزش حركتى، آزمون بيىبادى

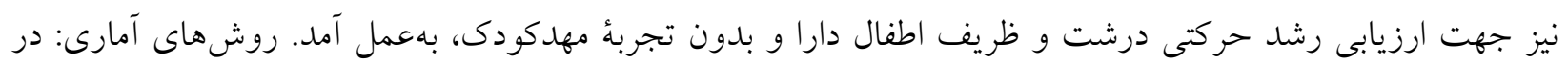
اين ئزوهش، ابتدا كليةُ نمرههاى خام آزمودنىها در هر يك از خرده مقياس هاى رشدحركتى درشت (بازتابها، حركات جابجايى و استوارى)، و ظريف (كرفتن و حركات مربوط به هماهنكى جشم و دست)، با استفاده از جـى ليستهاى

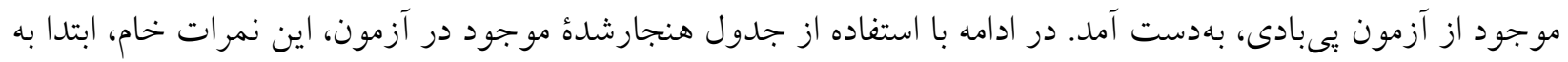
نمرات استاندارد Z تبديل و سبس به نمرههاى كلى بهرهُ رشدحركتى درشت و ظريف، تبديل شدند. در همين زمينه،

\section{Peabody development motor scales}

https://jrsm.khu.ac.ir/ 


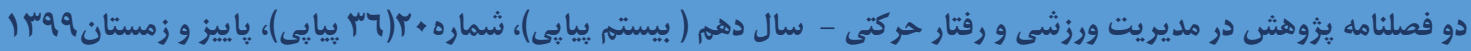

بهمنظور خلاصه و دستهبندى كردن اطلاعات از آمار توصيفى و به شكل محاسبة شاخصهاى مركزى و ير اكندگى (ميانكين و انحراف|ستاندارد)، استفاده شد. همجنين با استفاده از آمار استنباطى، براى ارزيابى ارتباط بين ميزان انكيزش حركتى و رشدحركتى درشت و ظريف در آزمودنىهاى يزوهش، از آزمون ضريب همبستى بيرسون و رگرسيون خطى و براى

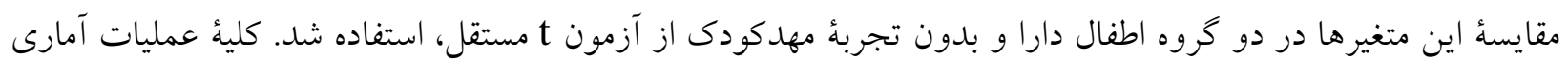

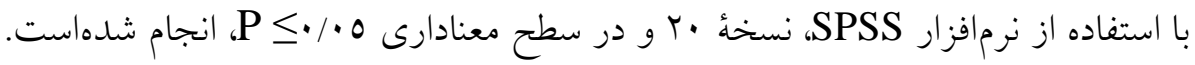

يافتهها

در يزوهش حاضر، بهمنظور ارزيابى طبيعىبودن توزيع دادهها، از آزمون كلموكروف اسميرنوف استفاده و نتايج نشان داد كه دادهها از توزيع طبيعى برخوردارند. هميجنين، بهمنظور بررسى بيشفرض برضئ برابرى واريانسها از آزمون لوين استفاده كرديد كه نتايج برابرى واريانس هاى دادهها در هر كروه را تأييد كرد. يافتهاى توصيفى:

ميانگين و انحراف معيار ويزّكى هاى آزمودنىها و متغيرهاى يزوهش: همانطور كه در جدول ا ملاحظه مىشود، ميانخين

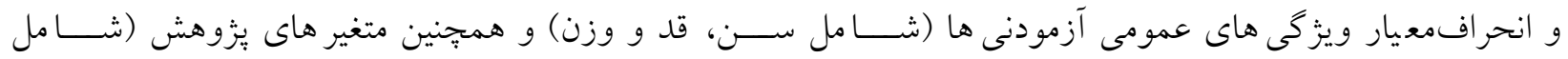
انخَيزش حركتى، ر شدحركتى در شت و همجنين ر شدحركتى ظريف) به تفكيك در اطفال دارا و بدون تجربهُ مهدكودى، ارائه شدهاست.

جدول ا. آمارههاى توصيفى مربوط به ويزگى هاى عمومى آزمودنى ها و متغيرهاى يزوهش

\begin{tabular}{|c|c|c|}
\hline اطفال بدون تجربئ مهدكودى & اطفال داراى تجربه مهدكودى & كرووها \\
\hline انحراف معيار 土 ميانخين & انحر اف معيار 土 ميانگين & \\
\hline $1 \cdot / \varepsilon V \pm 1 / \wedge$ & $1 \cdot / 0 \varepsilon \pm 1 / A V$ & سن (ماه) \\
\hline$V I / \neg\{ \pm \Lambda / r I$ & $v \cdot / 0\{ \pm q / \mu l$ & قد (سانتىمتر) \\
\hline$q / \varepsilon \pm \cdot / r \wedge$ & $q /| \pm| / T \mid$ & وزن (كيلوگرم) \\
\hline$|r \cdot / 7| \pm \mid r / 01$ & 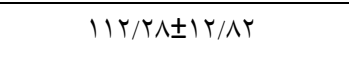 & نمرة كلى انخيزش حركتى \\
\hline $119 / r \cdot \pm / 11 / V T$ & $11 \cdot / 49 \pm 1 \cdot / 91$ & بهرة رشدحركتى درشت \\
\hline $11 r / r \cdot \pm 1 r / 10$ & $1 \cdot 9 / \mathrm{TV} \pm 1 \cdot / 10$ & بهرة رشدحركتى ظريف \\
\hline
\end{tabular}

يافته هاى استنباطى:

ارتباط بين انكيزشحركتى و رشدحركتى در اطفال دارا و بدون تجربهُ مهدكودك: همانطور كه در جدول تحليل همبستى

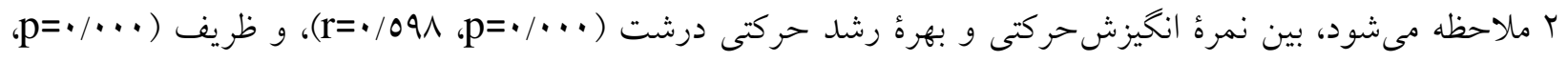

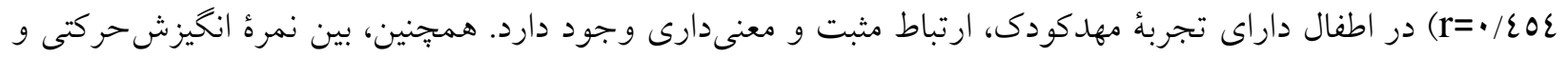




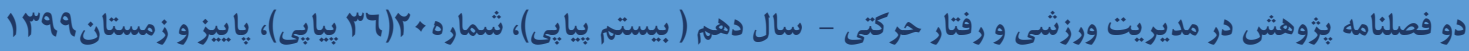

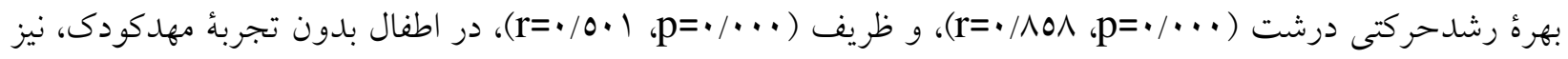
ارتباط مثبت و معنى دارى وجود دارد.

جدول r. ضريب همبستخى انخيزش حركتى با رشد حركتى درشت و ظريف در آزمودنى هاى يزوهش

\begin{tabular}{|c|c|c|c|c|}
\hline $\mathrm{P}$ & $\mathbf{R}$ & تعداد & متغيرها & 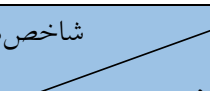 \\
\hline$\bullet \cdots$ & .1091 & 10 & بهرهُ رشد حركتى درشت & \multirow{2}{*}{ اطفال داراى تجربة } \\
\hline$\cdot \cdots$ & $\cdot / \varepsilon \circ \varepsilon$ & 10 & بهرهُ رشد حركتى ظريف & \\
\hline$\cdot \%$ & $\cdot / 101$ & 10. & بهرةٌ رشد حركتى درشت & \multirow{2}{*}{ اطفال بدون تجربئ } \\
\hline$\cdot \cdots$ & $\cdot 10.1$ & 10. & بهرهُ رشد حركتى ظريف & \\
\hline
\end{tabular}

همجنين، همانطور كه در جدول تحليل رگرسيون ب نشان داده شدهاست، مقدار R براى انخيزش حركتى اطفال داراى

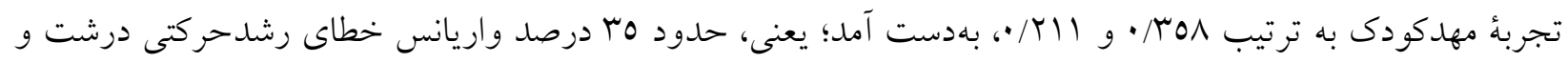
اب درصد واريانس خطاى رشدحركتى ظريف، در اطفال داراى تجربهُ مهدكودى به وسيلة ميزان انخيزش حركتى آنان قابل

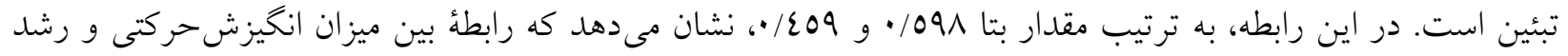

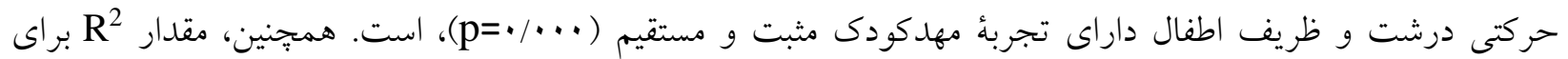

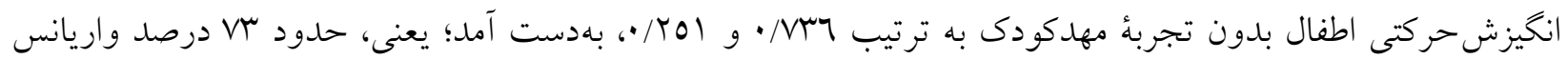
خطاى رشدحركتى درشت و

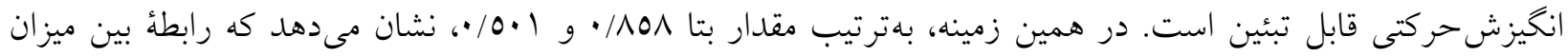

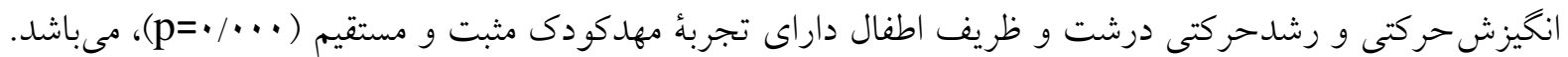
جدولب. تحليل رگرسيون؛ ييشبينى رشد حركتى بر اساس ميزان انخيزش حركتى در اطفال داراو بدون تجربهُ مهدكودى

\begin{tabular}{|c|c|c|c|c|c|}
\hline Sig & $\mathbf{R}^{2}$ & $\mathbf{T}$ & (بتا) B & متغير & گروه \\
\hline$\cdot \cdots$ & $\cdot /$ roN & $Q / \cdot v$ & $\cdot 1091$ & رشدحركتى درشت & \multirow{2}{*}{ اطفال داراى تجربهُ مهدكودى } \\
\hline$\cdot \cdots$ & $\cdot / \pi 11$ & $7 / 79$ &.$/ 209$ & رشدحركتى ظريف & \\
\hline$\cdot / \cdots$ & $\cdot / N r 7$ & $r \cdot / r \cdot$ & $\cdot / 101$ & رشدحركتى درشت & \multirow{2}{*}{ اطفال بدون تجربة مهدكودى } \\
\hline$\cdot \cdots$ & $\cdot / 701$ & $V / \cdot \varepsilon$ & .10 .1 & رشدحركتى ظريف & \\
\hline
\end{tabular}

https://jrsm.khu.ac.ir/ 
مقايسهُ انخيزش حركتى و رشد حركتى بين اطفال دارا و بدون تجربهُ مهدكودى: همانطور كه در جدول ع، و نمودار ا،

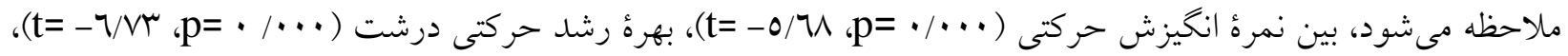

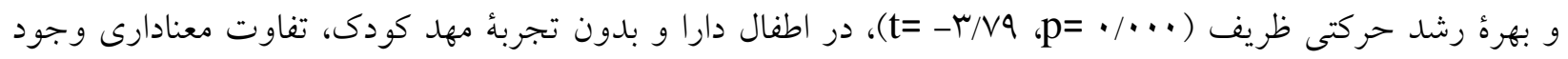
دارد و اطفالى كه تحت مراقبت و آموزش توسط والدين خودشان در محيط خانه هستند نسبت به اطفال تحت مراقبت و آموزش در مراكز مهدكودى از انخيزش حركتى، رشد حركتى درشت و نيز رشدحركتى ظريف بيشترى برخوردارند.

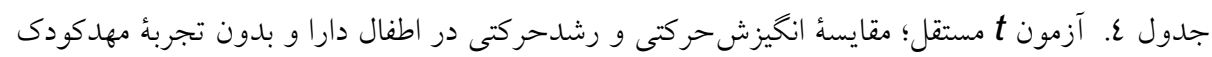

\begin{tabular}{|c|c|c|c|c|c|c|}
\hline Sig & df & $\mathbf{T}$ & انحراف معيار & ميانكين & كروه & \\
\hline \multirow[t]{2}{*}{$\cdot / \cdots$} & \multirow[t]{2}{*}{ ra1 } & \multirow[t]{2}{*}{$-0 / 71$} & IT/AT & $\| T / Y \Lambda$ & داراى تجربهُ مهد & \multirow{2}{*}{ انخَيزش حركتى } \\
\hline & & & $1 r / 01$ & $|r \cdot / 7|$ & بدون تجربه مهد & \\
\hline \multirow[t]{2}{*}{$\cdot / \cdots$} & \multirow[t]{2}{*}{ rqA } & \multirow[t]{2}{*}{$-7 / N r$} & $1 . / 9 T$ & $11 \cdot / r 9$ & داراى تجربئ مهد & \multirow{2}{*}{ رشدحركتى درشت } \\
\hline & & & $11 / V T$ & $119 / r$ & بدون تجربه مهد & \\
\hline \multirow{2}{*}{$\cdot \cdots$} & \multirow{2}{*}{ rqA } & \multirow{2}{*}{$-r / v a$} & $11 / 14$ & $1 \cdot 1 / 19$ & داراى تجربهُ مهد & \multirow{2}{*}{ رشدحركى ظريف } \\
\hline & & & $\mid r / 1 \Delta$ & $11 \pi / r$. & بدون تجربئ مهد & \\
\hline
\end{tabular}

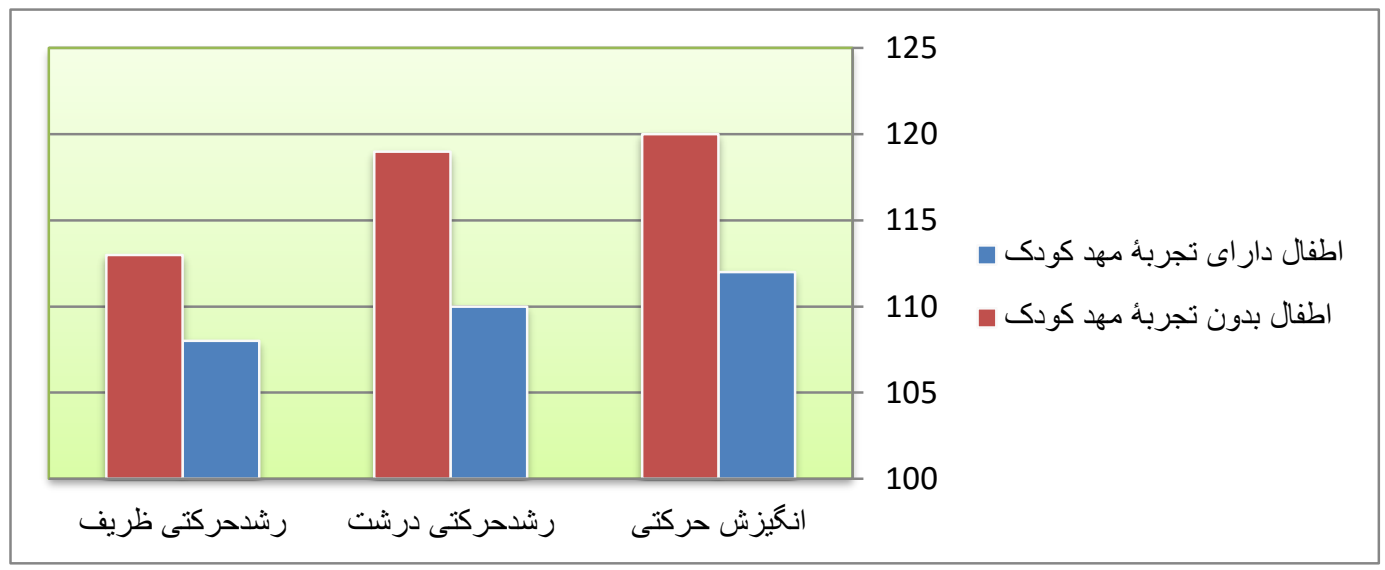

نمودار 1. مقايسٔ انكَيزشركتى و رشد حركتى درشت و ظريف، در بين اطفال دارا و بدون تجربئ مهد كودى 


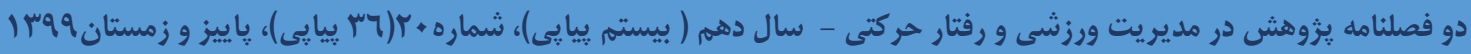

\section{بحث و نتيجه كيرى}

سؤالى كه از ديرباز محققان را به فكر وا داشته، اينست كه جرا اطفال حركاتى مانند سينهخيزرفتن، كه در انجام آنها به تبحر رسيدهاند را رها و تلاش مى كنند تا حركات و وضعيتهاى جديد و تجربه نشدهاى از قبيل راهرفتن را تجربه كنند (19). ادبيات يزوهشى ارتباط بين ويزگى هاى رشد حركتى اطفال و ديخر حوزههاى رشدى از قبيل رشد ادراكى

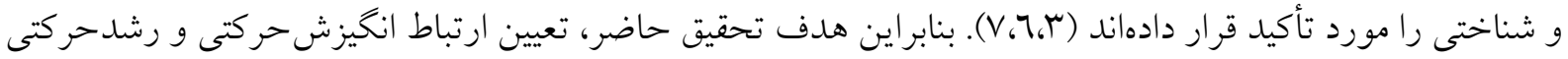
در اطفال •ا الى لالماهدُ دارا و بدون تجربهُ مهدكودى بود. در همين راستا، نتايج يزوهش حاضر نشان داد كه بين نمرهُ انخيزشحركتى و بهرهُ رشدحركتى درشت و ظريف (در اطفال دارا و بدون تجربهُ مهدكودى)، ارتباط مثبت و معنى دارى وجود دارد. درحاليكه در اين زمينه، يافته هاى يزوهشى ناهمسويى وجود ندارد. اين يافتها با نتايج تحقيقى

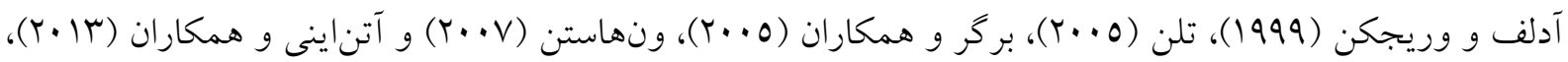
همسويى دارد. اخرجهه مطالعات أخير نشان دادهاند كه براى تجربة يكى وضعيت حركتى جديد مانند انتقال از حركت سينهخيزرفتن به راهرفتن هزينه و انرزى اندكى صرف مىشود (·T)، اما بسيارى از نظريههاى رشدى از انخَيزش براى حركت به عنوان يك متغير درونفردى حياتى جهت توضيح جرايى تلاش براى كسب بارزههاى حركتى جديد استفاده كردهاند (r). انخيزش براى حركت در اطفال مى تواند با مسائلى از قبيل حل نمودن يك يُزل، درى اجزاى يكى اسباب بازى جديد، تلاش و تمرين براى اكتساب يك مهارت حركتى جديد و همجنين با ميل به ادامه بازى يا انجام ديخر رفتارهاى اجتماعى در ارتباط باشد (T). ون هاستن (Y.V.V)، دو منبع مهم و حياتى كسب انكيزش براى حركت را شامل انكيزه اكتشافى و انخيزه اجتماعى دانسته است. اين دو منبع برانخيزاننده، از بدو تولد به عنوان يك سائق حركتى، نيروى رانشى اعمال و رفتارهاى حركتى در طول زندكى را فراهم مى كنند (7). در همين زمينه، انخيزهُ اكتشافى بلهوسيلة كنجكاوى جهت كشف اشياء جديد و مورد علاقه و همجنين فهم و درك قابليتهاى عملكردى خود فرد، افزايش مى يابد. براى مثال، اطفال در حالى كه مىتوانند به شكل ماهرانه و كار آمدى جهاردست و و يا بروند، اقدام به تلاش بر براى راهرفتن مى كنند. در واقع، كودكان الكوهاى تثبيت شدهُ رفتارى ييشين خود را به جهت كسب موقعيت هاى جديد، رها مى كنند. در اين فرآيند پِاداش بيرونى وجود ندارد و تنها ميل و انخيزش براى حركت اطفال به كونهاى عمل مى كنند كه در فعاليتهاى جديد ماهر شوند (r.r). كسب قابليتها و مهارت هاى حركتى جديد منجر به تثبيت مسيرهاى عصبى تازه، بهبود ادارى و تغييرات بيومكانيكى در اطفال مىشود. بنابراين، آنها با كسب هر موفقيت به كشف اشياء و رويدادهاى جديد در محيطشان مشتاق و مشتاقتر مىشوند ( آY). اين امر خود باعث مى شود تا كودكان روشهاى متنوع بسيارى را توسعه و تغييريذيرى ضرورى را در فرآيند يادكيرى مهارتهاى حركتى از خود نشان دهند (7). بنابراين، همانطور كه نتايج يزوهش حاضر نيز تأييد كنندة اين امر است، مىتوان ارتباط دوطرفه و مثبى را بين ميزان انگيزش حركتى و ميزان رشد حركتى اطفال، متصور شد. عنوان شده كه اطفال با انخيزش حركتى يايين، سطوح محدودى

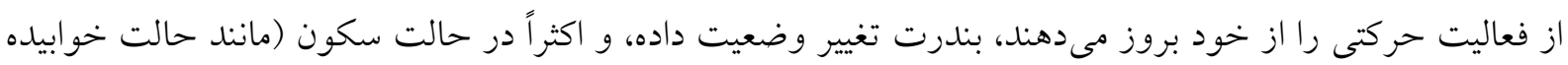




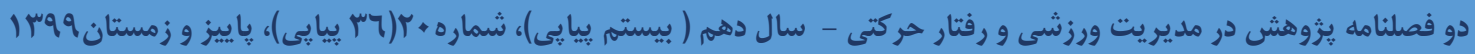

يا نشسته)، باقى مى مانند. اين اطفال، هنگامى كه ميل به انجام فعاليت بدنى يا حركت دارند، زمان زيادى را براى آغاز آن صرف مى كنند و سطح بايينى از شدت و طول مدت اجراى مهارت حركتى را نشان مى دهند. اطفال با انخيزش حركتى پايين، حتى با وجود تشويقهاى بيرونى فراوان براى حركت، تحرى و انخيختخى حركتى ناجيزى از خود نشان مى دهند. اين درحالى است كه اطفال داراى انخيزش حركتى بالا، اغلب به طور مداوم تغيير وضعيت مىدهند و نيازمند تحريك زياد براى شروع حركت نيستند. اين اطفال ترجيح مىدهند حركت خود را در مدت زمان طولانى ترى ادامه دهند و در

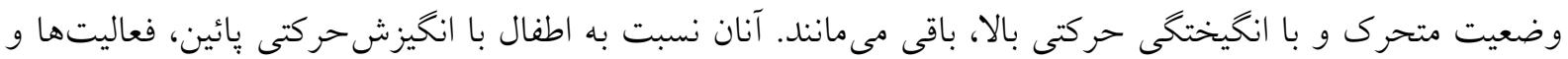
مهارتهاى حركتى كه مستلزم صرف انرزى بيشترى هستند (مانند بالارفتن از يله ها)، را انتخاب و اجرا مى كنند (Y). براين اساس، ارتباط مثبت و معنى دار بين انخيزش حركتى و رشدحركتى اطفال، مى تواند داراى اهميت نظرى و كاربرد روششناختى براى مداخله و همجنين اجراى طرحهاى درمانى باشند. مطابق با تجربيات بالينى متخصصين، تقويت انخيزش اطفال براى حركت مىتواند اثربخشى برنامهاى مداخلهايى حركتى را در حوزههاى مختلف كار آمدتر نمايد. هم:جنين، متخصصين كاردرمانى زمانى كه عوامل متأثركنندهُ اكتساب توانايىهاى حركتى را در نظر مى كيرند، بايد اهميت فوق العادهاى براى انكيزش حركتى متصور باشند. بهطوريكه كودكانى كه انخيزش حركتى بيشترى دارند احتمالاً اشتياق بيشترى براى مشاركت در برنامه هاى مداخله خواهند داشت. در همين زمينه، حتى بزشكان توصيه مى كنند كه

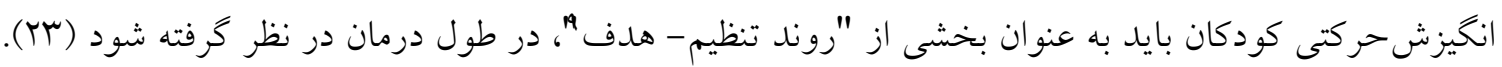
بخش ديخرى از نتايج يزٔوهش حاضر، نشان داد كه اطفال بدون تجربهُ مهدكودى در مقايسه با اطفال داراى تجربهُ مهدكودى، از انخيزشحركتى و رشدحركتى درشت و ظريف بالاترى برخوردارند. اين يافتهاى بزوهشى با نتايج

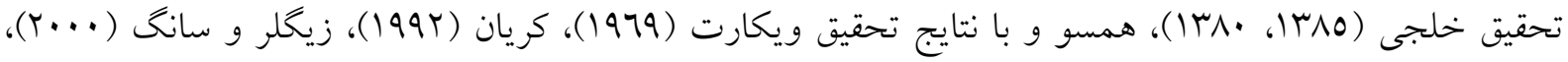

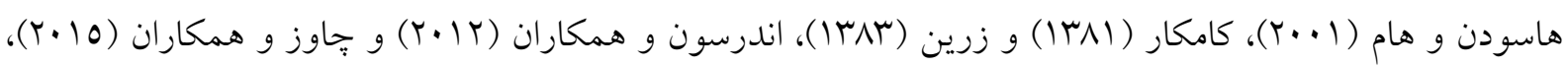
ناهمسو است. همانطور كه بيان شد، منبع ديخر كسب انخيزش براى حركت، انخيزش اجتماعى است. انخيزهُ اجتماعى، كودى را در زمينهُ وسيعى از تعاملات انسانى قرار داده و موجب كسب آسايش، امنيت و رضايتمندى مىشود. بلدون انكيزهُ اجتماعى، رشد همه جانبهُ كودكان در معرض خطر قرار مى گيرد. در واقع، تعاملات اجتماعى باعث تسريع در

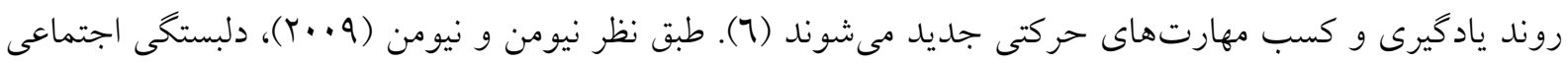
در دوران طفوليت به شكل فزايندهاى افزايش مى يابد. به دليل اينكه طفل كاملاً به مراقبان خود تكيه دارد، در اين زمان هر ارتباط متقابل اجتماعى، به علايق مراقبين او بستخى دارد. شكلى از دلبستخى اجتماعى اطفال، تلاشى است كه آنان براى حفظ نوعى تماس با اشياء مورد علاقهشان دارند (Yr). همجنين، اطفال با تعقيب ديدارى، خيرهشدن، كريه كردن و خنديدن، براى تماس اجتماعى تنگاتنگ با اشياء مورد علاقهشان و مراقب خود تلاش مى كنند. در ادامه، طفل در عمل جابجا شدن از طريق جهاردست و يارفتن و راه رفتن ماهر شده و اين قابليت جديد طفل را براى جستجوى مؤثر

\section{The "goal-setting process"}

https://jrsm.khu.ac.ir/ 


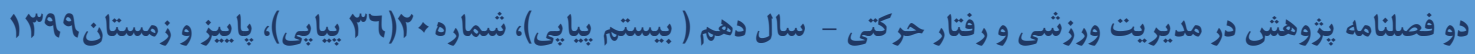

در محيط اطراف و تعامل با مراقب و اشياء مورد علاقهاش، توانا مىسازد. بنابراين، فعاليتهاى حركتى جديد و در حال توسعه نيز متقابلاً تعامل اجتماعى را تسهيل و كسترش مى دهند. تعاملات اجتماعى درحال رشد اطفال، فعاليت حركتى بيشترى را در آنها ارتقاء مىدهد. در واقع، ذخاير اجتماعى توسعهيافته، به طفل اين اجازه را مىدهد تا بلهورت فعال ترى با محيط تعامل برقرار كند و اين تعامل خود منجربه رشد، اكتساب و يادگيرى مهارتهاى حركتى خواهد شد (Y). در همين زمينه، با توجه به نتايج يزوهش حاضر، مىتوان كفت فر آيند دلبستكى اجتماعى در اطفال

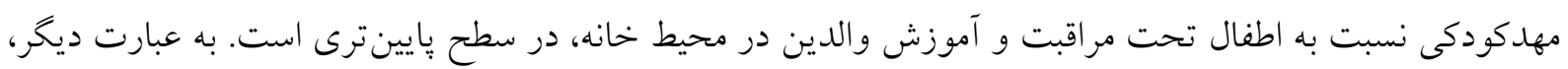
فرآيند دلبستخى اجتماعى در اطفال داراى تجربهُ مهدكودى بخوبى شكل نمى گيرد و اثرات منفى بر انخيزشحركتى و

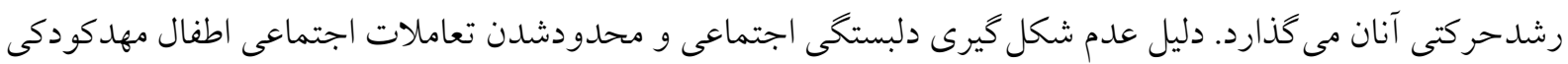
مى تواند؛ نسبت زياد تعداد اطفال تحت مراقبت به تعداد مربيان مهدكودك، عدم تخصص و آموزش مناسب مربيان و

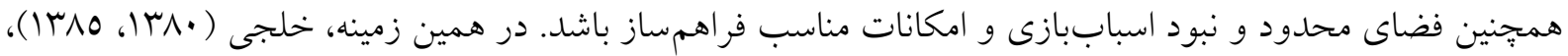
طى يزوهشهاى خود جهت بررسى ميزان اثر بخشى محيطهاى مراكز مهدكودى كزارش نمود كه اين مراكز از فضاى مناسب، برنامهها و فعاليتبدنى و نيز بازىهاى حركتى خوبى برخوردار نيستند. همجنين، وى گز ارش نمود كه مربيان اين مراكز نيز فاقد تخصصهاى لازم براى رشد همه جانبه كودكان هستند (1). در نتيجه، با توجه به اهميت مراكز مهدكودى بعنوان محيطهاى فراهمساز در عصر ماشينى شدن زندكى روزمره بشر، نتايج يزوهش حاضر لزوم بررسى هاى عميقتر در خصوص ميزان كارآيى برنامهها، امكانات و سطح دانش مربيان اين مراكز را مورد تأكيد قرار 
1. Gallahue DL, Ozmun GC, Goodway JD. Understanding Motor Development: Infants, Children, Adolescents, Adults. 7th Edition, Kindle Edition. 2012.

2. Payne VG, Isaacs LD. Human Motor Development a Lifespan Approach. Eight Edition, McGraw-Hill Higher Education. 2012.

3. Atun-Einy O, Berger SE, Scher A. Assessing motivation to move and its relationship to motor development in infancy. Infant Behavior and Development, 2013; 36(3), 457469.

4. Abdoli B. Psychosocial foundations of physical education and sports. Tehran, Bamdad Ketab Publications, 2005. In Persian.

5. Thelen, E. Dynamic systems theory and the complexity of change. Psychoanalytic Dialogues: 15., 255-283. 2005.

6. Von Hosteen C. Action in development. Developmental Science: 10. 54-60. 2007.

7. Berger SE, Adolph KE, Lobo SA. Out of the toolbox: Toddlers differentiate wobbly and wooden handrails. Child Development: 2005. 76., 1294-1307.

8. Khalaji $\mathrm{H}$. Investigating the relationship between anthropometric characteristics and motor performance of 6 to 8-year-old students with experience and without experience in Arak Kindergarten (2004-2005 academic year), Peyk Noor: 2004. No. 4 (3): 18-30. In Persian.

9. Loovis EM, Butterfield SA. Relationship of hand length to catching performance by children in kindergarten to grade 2 . Perceptual and motor skills. 2003 Jun;96(3_suppl):1194-6.

10. Weikartr D. A cooparative study of the preschool: curriculum, in C.seefeld(Ed). The Early childhood curriculum New arm armicha university. 1969. pp:20-29.

11. Zigler E, Valentine J. Project Head Start: A legacy of the war on poverty. 1979.

12. Housden T, Kam R. Full-Day Kindergarten: A Summary of the Research.1992.

13. Lemos AG, Avigo EL, Barela JA. Physical education in kindergarten promotes fundamental motor skill development. Advances in Physical Education. 2012 Feb 16;2(01):17.

14. Chaves R, Baxter-Jones A, Gomes T, Souza M, Pereira S, Maia J. Effects of individual and school-level characteristics on a child's gross motor coordination development. International journal of environmental research and public health. 2015 Aug;12(8):8883-96.

15. Doralp S, Bartlett D. Infant Movement Motivation Questionnaire: Development of a measure evaluating infant characteristics relating to motor development in the first year of life. Infant Behavior and Development. 2014 Aug 1;37(3):326-33.

16. Provost B, Heimerl S, McClain C, Kim NH, Lopez BR, Kodituwakku P. Concurrent validity of the Bayley Scales of Infant Development II Motor Scale and the Peabody Developmental Motor Scales-2 in children with 
developmental delays. Pediatric Physical Therapy. 2004 Oct $1 ; 16(3): 149-56$.

17. Rahmaniresa A. Determination of Peabody Development Motor Scale (PDMS) validity and reliability in 0-2 year-old infants of Tehran. Master of sciences dissertation, University of Welfare and Rehabilitation Sciences. 2008.

18. Farsi A, Abdoli B, Kaviani M, Kaviani A (2010). The effect of perceptualmotor experience on the motor development benefit of large and fine movements of 5-8 months old infants. Growth and learning of motorsports- No. 5- P.: 84-71. In Persian.

19. Shirley MM. The First Two Years. Vol. I, Postural and Locomotor Development; Vol. II, Intellectual Development; Vol. III, Personality Manifestations.1931.

20. Adolph KE, Cole WG, Komati M, Garciaguirre JS, Badaly D, Lingeman JM, Chan GL, Sotsky RB. How do you learn to walk? Thousands of steps and dozens of falls per day. Psychological science. 2012 Nov;23(11):1387-94.

21. Gibson EJ, Pick AD. An ecological approach to perceptual learning and development. Oxford University Press, USA; 2000.

22. Newman BM, Newman PR. Development through life: A psychosocial approach. Cengage Learning; 2017. Apr 12.

23. Winders PC. The goal and opportunity of physical therapy for children with Down syndrome. 2011. 